\title{
SOME REFLECTIONS ON THE TERMS OF TRADE
}

\author{
BY KJELD BJERKE
}

\begin{abstract}
In my article I have taken up different expressions for the terms of trade in foreign trade, and especially $I$ have been interested in a breakdown of total gain into two parts, namely the part due to the terms-of-trade effects and the part due to the price level effects. I have also taken up the intersectoral gain from terms of trade and the relation to the terms of trade in foreign trade. Besides the usual index for terms of trade--the ratio between output prices and input prices-I have also introduced another index for terms of trade corresponding to the relation between the output price index and an index consisting of a weighted average of input prices and prices for final demand. Finally I have tried to give some emperical findings which should throw light on the development of the Danish terms of trade for the period 1949 to 1964.
\end{abstract}

\section{TheORETICAL CONSIDERATIONS}

It will be generally known that when in the national accounts statistics we operate solely with the identity

$$
P+I=C+I v+E^{1}
$$

which expresses flows of goods and services, a deflation will also give agreement. Stone [1], among others, has pointed out, however, that if $P$ is given at factor cost and $\mathrm{C}$ and $\mathrm{Iv}$ at market prices, the identity at constant prices cannot be fulfilled. However, it would be possible also in this case to obtain agreement if an entry is introduced for deflated indirect taxes, etc., which need not be determined as a remainder.

The result would thus be at market prices:

$$
\mathrm{P}^{\prime}+\mathrm{I}^{\prime}+\mathrm{T}^{\prime}=\mathrm{C}^{\prime}+\mathrm{Iv}^{\prime}+\mathrm{E}^{\prime 2}
$$

This agreement is based on the usual index considerations where interdependence between price and quantity is not assumed. In other words, what may be called an atomistic index theory is adopted. This is, of course, the method used in the deflation of the national accounts, so I shall not discuss the consideration that if we abandon the assumption that price and quantity are independent, we should be using a functional approach, taking into account as Ragnar Frisch has done, the connection between price and quantity, cf. [2]. This question in relation to the national accounts is discussed in more detail in [1].

The difficulties from the mentioned assumptions where an atomistic index theory is adopted arise, for instance, when the money flows we operate with have no corresponding commodity or service flows as in the case of saving, depreciation or the surplus on the current items of the goods and services in the balance of payments.

Such entries are characterized by being money flows with no directly corresponding commodity flows.

Further, the discrepancies between a deflation of the production side and the

1. $\mathbf{P}=$ Domestic Product, $\mathbf{I}=$ Import, $\mathrm{C}=$ Consumption, $\mathrm{Iv}=$ Investments, $\mathrm{E}=$ Export .

2. $\mathbf{T}^{\prime}=$ Deflated Indirect Taxes. 
income side will depend on changes in relative prices. These changes will lead to the real product being replaced by another income concept-seen from an income point of view-namely real income, which shows a different development.

Now, to express, for a country as a whole, the adjustment to be made in order to proceed from real product to real income, an attempt will be made to estimate gains and losses from changes in the external terms of trade.

It is generally known that it is possible, a priori, to set up many different measures of gains and losses from changes in the terms of trade. It will therefore be possible to get many different measures of the adjustments to be made in order to get from real product to real income.

It may be of importance to discuss different measures of terms of trade also from the point of view that there may be a more rational case for some measures than for others. I shall go through the points of view of some authors.

Nicholson has stressed in [4] that the following formula should be used in estimating gain from terms of trade (for year 1 compared with the base year):

$$
\mathrm{G}=\mathrm{E}_{1}\left(\frac{1}{\mathrm{p}_{1_{1}}}-\frac{1}{\mathrm{p}_{\mathrm{E}_{1}}}\right)^{3}
$$

Accordingly he deflates exports by means of an import price index, and the argument is as follows:

"The estimates adjusted for the terms of trade thus include the estimated value of imports at base year prices which can be purchased with the current value of exports. Exports are here regarded as a source of foreign currency and the result is affected only by changes in the money value of exports, whether resulting from changes in the prices or from changes in the volume of exports."

As the formula is designed, the figures are brought down to base year level. In [1], page 95, Stone has stated in this connection that since exports finance purchases of imports, it must seem "appropriate to deflate the value of exports by means of the import (not export) price index." However, he adds that it cannot be reasonable to deflate an export surplus since this is not used to finance the actual level of imports. It will not do "counting chickens before they are hatched."

To this Nicholson states: "Such surplus income is, however, part of the gross national product so that the chickens, whether hatched or not, must be given some value. As the object is to measure income in terms of the goods and services available for use, and this income is not used to purchase exports, deflation by the export price index is not appropriate. The best (at any rate the first) approximation to the potential gain or loss from changes in the terms of trade associated with a balance of payments surplus is obtained by deflating by the import price index."'

Geary [5] seems to have accepted Stone's point of view, using a different deflation according as the export surplus is positive or negative. If exports are higher than imports, the following formula is used for the estimation of gain from terms of trade:

$$
\mathrm{G}=\mathrm{I}_{1}\left(\frac{1}{\mathrm{p}_{\mathrm{I}_{1}}}-\frac{1}{\mathrm{p}_{\mathrm{E}_{1}}}\right)
$$

3. $p_{I_{1}}$ is the price index for imports, $p_{E_{1}}$ is the price index for exports. In the base year the index is 1.0 . 
If, on the other hand, imports are higher than exports, the following formula is used:

$$
G=E_{1}\left(\frac{1}{p_{I_{1}}}-\frac{1}{p_{E_{1}}}\right)
$$

In the case of an export surplus account is thus taken only of the part of exports which is used to finance current imports, while in the case of an import surplus account is taken only of the imports which are financed through current exports.

In [6] Stuvel has dissociated himself from this alternative method. On this point the following is said (p. 267):

"It should be noted that the mention of a third possibility, namely basing the calculation on either total imports or total exports according to whichever of the two has the lowest value in the current year, has been carefully avoided. This has been done intentionally, for the application of this method leads to odd results, as can readily be seen from the following extreme example. Suppose all of a country's imports take place in the first half of the year and all of its exports in the second half. What would be the effect of changes in the terms of trade, calculated on the basis of this method for half-yearly periods and for yearly periods? For half-yearly periods the effect would always be zero, no matter what changes took place in the import and export prices, for the lowest value of the two (imports and exports) would always be zero. For yearly periods the story, however, would be a different one as there would be a certain amount of exports covered by imports, or the other way round, and so the effect of changes in the terms of trade would clearly differ from zero. In other words the half-yearly and the yearly calculations would render results which are incompatible with each other."

With regard to the export surplus Stuvel [7] argues that it can be deflated by the price index for the domestic product as an expression of changes in the purchasing power of money. On the whole, Stuvel argues that non-commodity flows should be deflated by such an index. He says:

"So far so good, but what about the other items in the national accounts, the non-commodity flows? To them applies with equal force the statement made by Stone in the opening paragraph of his study: "The pound note of 1955 may look similar to the pound note of 1938 but in terms of what it will buy it is different" (op. cit., p. 9). Here too, therefore, one would like to correct for changes in the purchasing power of money in making comparisons over time between the national accounts of different periods. The problem one is faced with here is to select an appropriate price index for this purpose, since the non-commodity flows do not have specific price indices of their own. As with so many problems in national accounting, this is one which can be solved only by introducing a convention, for in the last resort the choice is an arbitrary one.

In order to make the convention as acceptable as possible, it is clearly desirable to choose an index of wide coverage so as to guarantee that its movements properly reflect the general tendency of price developments. This condition narrows the choice considerably; so much so, in fact, that there is very little choice left. For one thing, indices of wide coverage are few in number, and for another they normally follow, with only slight variations between them, the same development over time. 
Examples of such indices that come to mind immediately are the price indices of total expenditure $(\mathrm{C}+\mathrm{K})$, total output $(\mathrm{C}+\mathrm{K}+\mathrm{E})$, and total product $(C+K+E-M)$. Of these, the latter has in a sense the widest coverage. Also it has the advantage that it is free of foreign elements, reflecting, as it does, the price development of a given combination of home factors of production of constant productivity. And last but not least, it is the only price index in the production account specifically constructed for the deflation of a non-commodity flow (factor income). I would, therefore, recommend that the product price index $\left(\mathrm{p}^{y}\right)$ be chosen as a common deflator. Where there is a choice between price indices of gross and net product, the latter would obviously deserve preference, since it is entirely free of duplication. Moreover, if there is a choice between national and domestic product, the domestic-product price index is an obvious choice, since national product, as distinct from domestic product, includes non-commodity flows in the form of factor income to and from abroad; the national-product price index cannot be determined within the framework of the production account with the help of the Geary method unless special conventions are introduced for the deflation of those non-commodity flows which have no specific price index of their own attached to them. Finally, if there is a choice between market-price and factor-cost valuation I would prefer the market-price concept, since that is the price concept that underlies all economic transactions. Ideally, therefore, it is the price index of the net domestic product at market prices that should be used as a common deflator for the whole system of national accounts."

He also mentions that goods and service flows can be deflated in this way-i.e. a different deflation of production account.

The difference which appears in the figures, he underlines, reflects a pricestructure effect, and on this subject he says:

"In other words, these price-structure effects measure the real income gains that result from the change in the relative prices of the commodities purchased. They might, therefore, also be labelled 'income exchange benefits' or 'income gains' for short."

For any sector-including the rest of the world sector-gain from terms of trade can be defined in the following way, cf. [8] and [9]. ${ }^{4}$

$$
\left(P_{1} Q_{1}-p_{1} q_{1}\right)-\left(P_{0} Q_{1}-p_{0} q_{1}\right)
$$

The formula shows the difference between output and input in current and constant prices, respectively. The difference solely reflects the influence of changes in prices. For foreign trade this can be written as follows:

$$
\left(p_{E_{1}} q_{E_{1}}-p_{I_{1}} q_{I_{1}}\right)-\left(p_{E_{0}} q_{E_{1}}-p_{I_{0}} q_{I_{1}}\right) \text { or }(E-I)-\left(E^{\prime}-I^{\prime}\right)
$$

4. The introduction to chapter 13 in [9] contains the following remarks:

"The concept of a gain from changes in the terms of trade has played a considerable role, not only in economic theory, but also in the debate on economic policy in many countries.

"In appendix A of his study of inter-sectoral relations (P. Nørregaard Rasmussen, Studies in Inter-Sectoral Relations, Copenhagen and Amsterdam 1956), which concentrates on input-output models, P. Nørregaard Rasmussen discusses various concepts of a gain from terms of trade in foreign trade and shows how different concepts will lead to different results (cf. op. cit., pp. 161-72). The following comments deal with similar problems; however, the analysis is limited to two years. In a review of this work, T. Haavelmo (T. Haavelmo, "Kryssløpsanalysen som teoretisk og som økonomisk-politisk instrument," Nationalokonomisk Tidsskrift, 1956, pp. 111-112) pointed out that these problems are not confined to inpui-output models, but that the problem is a general one for any sector (a country, an industry, a firm, etc.) which buys and sells goods. 
Now, it is possible that even ii the relation between export and import prices remains unchanged-i.e., the index for terms of trade is not changed-a gain may arise if prices change. It must therefore be of interest to alter the above expression in such a way as to get a term expressing solely the effect of changes in the relation between export and import prices-the terms-of-trade effect-and a term showing the effect of a change in prices-the price-level effect.

If the index for import prices is regarded as an expression of the terms-of-trade effect, the first term in the above formula can be deflated by the index for imports, $p_{i_{1}}$.

The result will-for a year chosen at random-be:

$$
\frac{\mathrm{E}}{\mathrm{p}_{\mathrm{I}}}-\frac{\mathrm{I}}{\mathrm{p}_{\mathrm{l}}}-\mathrm{E}^{\prime}+\mathrm{I}^{\prime}=\mathrm{E}\left(\frac{1}{\mathrm{p}_{\mathrm{I}}}-\frac{1}{\mathrm{p}_{\mathrm{E}}}\right)
$$

that is, precisely the above-mentioned expressions of gain from terms of trade. The difference between this expression and the preceding one should consequently express the price level effect. The expression will be as follows:

$$
(E-I)-\frac{1}{p_{1}} \cdot(E-I)
$$

However, this expression seems to contain a terms-of-trade effect, viz. in E - I.

It can be shown that if it is desired to find two pure expressions of the terms-oftrade effect and the price-level effect, this can, on the basis of the given assumption, be expressed as follows:

$$
(E-I)-\left(E^{\prime}-I^{\prime}\right)=E^{\prime}\left(p_{E}-p_{1}\right)+\left(p_{1}-1\right)\left(E^{\prime}-I^{\prime}\right)
$$

The first term expresses the terms-of-trade effect, the second the price-level effect. In the following I shall compare some of these expressions based on Danish figures for the period 1949-1965.

t. mentioned, the following identity equation exists also in constant prices:

$$
\mathrm{P}^{\prime}+\mathrm{I}^{\prime}{ }_{1}=\mathrm{C}^{\prime}+\mathrm{I}^{\prime}{ }{ }+\mathrm{E}^{\prime}
$$

This may be written as follows:

$$
\begin{aligned}
& E^{\prime}-I^{\prime}=P^{\prime}-\left(C^{\prime}+I^{\prime}{ }_{v v}\right) \\
& E^{\prime}-I^{\prime}=P^{\prime}-\operatorname{Exp}^{\prime} \text { where }\left(C^{\prime}+I^{\prime}{ }_{1 v}\right)=\operatorname{Exp}^{\prime}
\end{aligned}
$$

The gain from terms of trade may consequently be expressed through the domestic factrrs menticned, viz. domestic product $P$ and expenditure Exp:

$$
\begin{aligned}
& G=\left(p_{P_{1}} \cdot q_{P_{1}}-p_{E x p_{1}} \cdot q_{E x p_{1}}\right)-\left(p_{P_{0}} \cdot q_{P_{1}}-p_{E x p_{0}} \cdot q_{E x p_{1}}\right) \\
& G=(P-E x p)-\left(P^{\prime}-E x p^{\prime}\right)
\end{aligned}
$$

This expression can be solved in the following two terms: ${ }^{5}$

$$
\mathrm{P}^{\prime}\left(\mathrm{p}_{\mathrm{P}}-\mathrm{p}_{\mathrm{Exp}}\right)+\left(\mathrm{p}_{\mathrm{Exp}}-1\right)\left(\mathrm{P}^{\prime}-\operatorname{Exp}^{\prime}\right)
$$

The first term expresses the terms-of-trade effect and the second the price-level effect.

5. The expression corresponding to $\mathrm{E}\left(\frac{1}{\mathrm{p}_{\mathrm{I}}}-\frac{1}{\mathrm{p}_{\mathrm{E}}}\right)$ will consequently be $\mathrm{P}\left(\frac{1}{\mathrm{p}_{\mathrm{E} \times \mathrm{p}}}-\frac{1}{\mathrm{p}_{\mathrm{p}}}\right)$. 
It also follows from the above that

$$
\begin{aligned}
E^{\prime}\left(p_{E}-p_{I}\right) & =P^{\prime}\left(p_{P}-p_{E x p}\right) \\
\left(p_{I}-1\right)\left(E^{\prime}-I^{\prime}\right) & =\left(p_{E x p}-1\right)\left(P^{\prime}-E x p^{\prime}\right)
\end{aligned}
$$

If these agreements exist, it must be of interest to study the price relations between foreign trade and the domestic economy. The prices for which a comparison would be relevant must be the following: (1) import price index with index for expenditure $\operatorname{Exp}=(C+I v)$, and (2) terms of trade index in foreign trade with index for the relation between price index for domestic product and price index for expenditure.

I shall now very briefly advance some reflections on the gain from terms of trade for the individual domestic sectors, based on the points of view set out in [8] and [9].

If we imagine an open economy, the real product for an individual sector can be defined as follows, on the assumption that there are three domestic sectors and one external sector.

$$
\begin{aligned}
\mathrm{X}_{\text {va1 }_{1}}^{\prime} & =\mathrm{X}_{01}^{\prime}-\mathrm{X}_{21}^{\prime}=\mathrm{X}_{31}^{\prime}-\mathrm{X}_{\mathrm{I}_{1}}^{\prime} \\
\mathrm{X}_{01} & =\text { output for sector } 1 \\
\mathrm{X}_{21} \text { and } \mathrm{X}_{31} & =\text { input to sector } 1 \\
\mathrm{X}_{\mathrm{I}_{1}} & =\text { import to sector } 1
\end{aligned}
$$

This is value added in constant prices (the real product), and the deflation has been made from a production point of view.

If it is desired to find the real income of the sector in question, i.e. to adopt an income point of view, or if it is desired to obtain an expression of the purchasing power, value added in current prices must be deflated by a price index for final demand. Real income will then be:

$$
\frac{X_{\mathrm{va}}}{\mathrm{p}_{\mathrm{D}}}
$$

Total real product for the economy becomes:

because $\mathrm{X}_{\mathrm{va}}^{\prime}+\mathrm{X}_{\mathrm{I}}^{\prime}=\mathrm{X}_{\mathrm{D}}^{\prime}+\mathrm{X}_{\mathrm{E}}^{\prime}$.

$$
\mathrm{X}_{\mathrm{va}_{1}}^{\prime}=\mathrm{X}_{\mathrm{va}_{1}}^{\prime}+\mathrm{X}_{\mathrm{va}_{2}}^{\prime}+\mathrm{X}_{\mathrm{va}_{3}}^{\prime}=\mathrm{X}_{\mathrm{D}}^{\prime}-\left(\mathrm{X}_{\mathrm{I}}^{\prime}-\mathrm{X}_{\mathrm{E}}^{\prime}\right) \text {, }
$$

Here $\mathrm{X}^{\prime}{ }_{\mathbf{v a}}$ is value added in constant prices and $\mathbf{X}_{\mathbf{D}}^{\prime}$ is total final demand, i.e. consumption + investments in constant prices. In a similar way the following expression is obtained for total real income:

$$
Y^{\prime}=\frac{X_{v a}^{\prime} \cdot p_{v a}}{p_{D}}=X_{D}^{\prime}-\frac{\left(X_{D}^{\prime} \cdot p_{I}-X_{E}^{\prime} \cdot p_{E}\right)}{p_{D}}=X_{D}^{\prime}-\frac{I-E}{p_{D}}
$$

On the background of these reflections the individual sector gain can be defined from a production point of view and an income point of view, respectively, as follows:

$$
\begin{aligned}
\text { Gain }_{\text {prod }} & =X_{\text {va }_{1}}^{\prime} \cdot\left(p_{v_{v_{1}}}-p_{v_{v}}\right) \\
\text { Gain }_{\text {income }} & =X_{\text {va }_{1}}^{\prime} \cdot\left(p_{v_{a_{1}}}-p_{D}\right)
\end{aligned}
$$

As may be expected, the terms of trade are from a production point of view 
measured by the term $p_{v_{1}}-p_{v a}$ and from an income point of view by the term $\mathrm{p}_{\mathrm{va}_{1}}-\mathrm{p}_{\mathrm{D}}$.

The sum of gain prod $_{\text {becomes }}$, but this does not apply to gain income, which becomes $\mathrm{X}_{\mathrm{va}}^{\prime}\left(\mathrm{p}_{\mathrm{va}}-\mathrm{p}_{\mathrm{D}}\right)$. At the same time gain from foreign trade becomes:

$$
\left(p_{E_{1}} \cdot q_{E_{1}}-p_{I_{1}} \cdot q_{I_{1}}\right)-\left(p_{E_{0}} \cdot q_{E_{1}}-p_{I_{0}} \cdot q_{I_{1}}\right)=X_{E_{1}}-X_{I_{1}}-\left(X_{E_{1}}^{\prime}-X_{I_{1}}^{\prime}\right)
$$

This expression includes a level effect, as previously demonstrated. If the first part of the expression is deflated by $p_{D_{1}}$ and not by $p_{I_{1}}$, as above, and if also the expression for $G_{\text {income }}$ for the individual sectors is deflated by $p_{D_{1}}$ the sum of the gains from the individual sectors will correspond to gain from terms of trade in foreign trade, i.e. $g_{1}+g_{2}+g_{3}=$ g or

$$
\begin{aligned}
& \frac{1}{p_{D}} X_{v_{1} a_{1}}^{\prime}\left(p_{v_{1}}-p_{D}\right)+\frac{1}{p_{D}} X_{v_{a_{2}}}^{\prime}\left(p_{v_{2}}-p_{D}\right)+\frac{1}{p_{D}} X_{v_{3}}^{\prime}\left(p_{v_{3}}-p_{D}\right) \\
& =\frac{X_{\mathrm{va}}^{\prime}}{\mathrm{p}_{\mathrm{D}}}\left(\mathrm{p}_{\mathrm{va}}-\mathrm{p}_{\mathrm{D}}\right)=\frac{1}{\mathrm{p}_{\mathrm{D}}}\left(\mathrm{X}_{\mathrm{E}}-\mathrm{X}_{\mathrm{L}}\right)-\left(\mathrm{X}_{\mathrm{E}}^{\prime}-\mathrm{X}_{\mathrm{l}}^{\prime}\right)
\end{aligned}
$$

It is in a way nearly the same result as I have obtained above.

By analogy and in addition to the usual index for terms of trade (Terms of Trade I), which corresponds to the relation between the output price index and the input price index, another index can be introduced from a purchasing power point of view corresponding to the relation between the output price index and an index consisting of a weighted average of input prices and prices for final demand (Terms of Trade II).

The assumptions for being able to apply such calculations seem rather strict. On this point the following is said in [9], page 265:

"This interpretation requires two additional assumptions to those involved in tables 14.1 and 14.2. First, it must be assumed that each sector in the base year (here year 2) purchases final goods exactly corresponding to its value added. This assumption is crucial; it implies that no claims on other sectors are acquired. Secondly, it is assumed that all industries buy final goods in the same proportion, viz. the proportions of goods in total final demand, cf. table 14.2."'

In [9], page 266 , Ølgaard gives an excellent example which illustrates the importance of introducing index II. He says as follows:

"The fact that a terms-of-trade index according to (14.9) and not one of the type of (14.6) is relevant from a gain point of view may be illustrated by a simpl c example. Assume that output prices of sector 1 decline by 10 per cent and input prices by 20 per cent; hence, the terms of trade according to (14.6) have improved. If, however, the sector has to buy final goods at an unchanged price level ${ }^{6}$, it may only be able to acquire a smaller amount of final goods after the price change than before, and hence it may have suffered a loss. This aspect is covered by (14.9), which may show a deterioration for sector $1 . "$

Assuming that the balance of payments is in equilibrium in year 1, it can be shown that the stated expression for terms of trade II for a single sector can be defined indirectly if real product and real income for the sector in question are

6. These assumptions are not inconsistent. E.g., output prices of sector 2 may decline by 25 per cent and output prices of sector 3 increase by 10 per cent, industry buying most of its input from sector 2 , but most of its final goods from sector 3 . 
known. It can, in fact, be shown, cf. [9], pages $274 / 75$ and 282 , that under the mentioned assumptions index II will be as follows:

$$
\mathrm{T}_{\mathrm{II}}=\left(\frac{\mathrm{X}_{\mathrm{va} 1}^{\prime}}{\mathrm{X}_{\mathrm{0}_{1}}} \cdot \frac{\text { real income }}{\text { real product }}-1\right)+1
$$

It is thus possible to calculate changes in terms of trade for the individual sectors from an income point of view when real product and real income have been calculated.

Ølgaard has, for a longer period, calculated the mentioned terms of trade for Danish agriculture and underlines, in connection with method II, what has been stated above, viz. (p. 284): "that the final demand of agriculture follows the same pattern as total final demand, or at least that the prices of final goods acquired by agriculture show the same development as prices of total final demand ${ }^{7}$."

In the following section I shall consider the development in the terms of trade for Denmark during the post-war years, partly in the case of foreign trade and partly in the case of individual sectors, e.g., agriculture and certain other industries.

Still assuming equilibrium in year 1 on the balance of payments, it is possible to calculate the share of gain from changes in the terms of trade in foreign trade which falls on the individual domestic sectors. The result is:

$$
\mathrm{X}_{\mathrm{E}}^{\prime}(\mathrm{T}-1)=\mathrm{X}_{01}^{\prime}\left(\mathrm{T}_{\mathrm{II}_{1}}-1\right)+\mathrm{X}^{\prime}{ }_{02}\left(\mathrm{~T}_{\mathrm{II}_{2}}-1\right)+\mathrm{X}^{\prime}{ }_{03}\left(\mathrm{~T}_{\mathrm{II}_{3}}-1\right)
$$

$T$ is defined in the usual way, and the definition of $T_{I I}$ has been accounted for . Finally, $\mathrm{X}_{01}^{\prime}$ etc. is, as already mentioned, output in constant prices.

The examination of the different measures of gain from changes in terms of trade in foreign trade has shown, as already underlined, that there are many solutions. The solution advanced by Nicholson and Stuvel is probably the one which has found greatest favour. Geary's modification of the basis of calculation, on the other hand, does not seem to have been generally accepted even though it is the logical consequence of Stone's points of view. The calculation of gain on which Nørregaard Rasmussen and Ølgaard have been working makes it necessary to decide whether gain can be affected by both changes in terms of trade and a price-level effect.

On the assumption that the price-level effect is to be measured on the basis of changes in the import price, I have tried to set up two terms in the formula for gain from changes in terms of trade one for the terms-of-trade effect and one for the price-level effect.

From the consideration that it must be relevant to estimate changes in the gain from the terms of trade in foreign trade in such a way that the sum of intersectoral gains corresponds to the gain from the terms of trade in foreign trade, Ølgaard sets up another formula for the gain from the terms of trade in foreign trade in which a deflation is undertaken by means of a price index for final demand. On the whole, Nørregaard Rasmussen and Ølgaard discuss in detail the problems concerning real product and real income both for all sectors and for the individual sectors. There-

7. The same assumption was implied when terms of trade II was measured directly, cf. table 15.4, since here the purchases of final goods by agriculture were deflated by a price index of all final goods. 
fore, considerations of gain are introduced from a production point of view (real product) and from an income point of view (real income). This naturally leads to a distinction between two indices for the terms of trade: the usual index expressed as the relation between output and input prices, and an index from an income point of view as corresponding to the relation between output prices and input prices plus prices for final demand.

In the following, as mentioned above, I shall carry out some calculations concerning Denmark of the various gains and indices for the terms of trade for the period from 1949 to 1964 .

\section{EMPIRICAL FINDINGS}

In the following I shall try to throw light on the development in the Danish terms of trade for the period 1949 to 1964.

The beginning of the period is, of course, characterized by, among other things, the Korean and the Suez crises, and the end of the period by rapid expansion.

\section{Gain from terms of trade in foreign trade}

I shall start by illustrating the gain from the terms of trade in foreign trade. Table 1 shows the development in the gain from foreign trade, defined as: $(E-I)-\left(E^{\prime}-I^{\prime}\right)$; and, as discussed in the first section, not only has the usual expression of terms of trade $\mathrm{E}\left(\frac{1}{\mathrm{p}_{\mathrm{I}}}-\frac{1}{\mathrm{p}_{\mathrm{E}}}\right)$ been shown, but also the remainder item, which does not exclusively show the price-level effect.

Throughout the period there has thus been a quite considerable negative gain (loss?). It reaches a peak in 1951 at the time of the Korean crisis, and as a general tendency this is followed by a fall, so that in 1959 there is almost a balance. Then there is again a relatively high negative gain during the following three years, which is superseded by a negative gain at a substantially lower level.

The special expression of the terms of trade effect $\left(E\left(\frac{1}{p_{I}}-\frac{1}{p_{E}}\right)\right)$ shows the same movement as for total gain; however, it will be noted that in 1964 there is a very small positive figure for the development in the terms of trade; as far as the relative prices are concerned we are thus back to the conditions of the base year.

Since, as mentioned, the breakdown I have made of gain gives pure expressions of the terms-of-trade effect and the price-level effect, respectively, I shall go a little more deeply into the development for the period 1949-64 which will be seen from Table 2.

The movements are similar to those in Table 1. It will perhaps be noted that the "real" price-level effect, for which the figures are mainly positive, means a great deal more than the remainder figures arrived at in Table 1. This, of course, applies to the years 1951 to 1953 with the Korean and the Suez crises. The index for import prices $(1949=100)$ was 138 in 1951, almost the same as in 1952, viz. 136, and 124 in 1953. Also, and in particular, for the years 1957 and 1958 the effect is substantial. The index for import prices was 131 in 1957, i.e., the highest index of the period, and 122 in 1958. 
TABLE 1

Gain From Foreign Trade

(Millions of kroner)

\begin{tabular}{lccc}
\hline & $\begin{array}{c}\text { Gain } \\
(E-I)-\left(E^{\prime}-I^{\prime}\right)\end{array}$ & $E\left(\frac{1}{p_{I}}-\frac{1}{p_{E}}\right)$ & $(E-I)-\frac{1}{p_{I}}(E-I)$ \\
\hline 1949 & 0 & 0 & 0 \\
1950 & -582 & -518 & -64 \\
1951 & -1188 & -1132 & -56 \\
1952 & -740 & -800 & 60 \\
1953 & -650 & -684 & 34 \\
1954 & -627 & -554 & -73 \\
1955 & -500 & -553 & 53 \\
1956 & -463 & -457 & -6 \\
1957 & -704 & -791 & 87 \\
1958 & -473 & -638 & 165 \\
1959 & -49 & -76 & 27 \\
1960 & -473 & -406 & -67 \\
1961 & -724 & -617 & -107 \\
1962 & -611 & -357 & -254 \\
1963 & -231 & -290 & 59 \\
1964 & -208 & 10 & -218 \\
\hline
\end{tabular}

TABLE 2

Gain From Foreign Trade

(Millions of kroner)

\begin{tabular}{cccc}
\hline \hline & $\begin{array}{c}\text { Gain } \\
(\mathrm{E}-\mathrm{I})-\left(\mathrm{E}^{\prime}-\mathrm{I}^{\prime}\right)\end{array}$ & $\begin{array}{c}\text { Terms-of-trade } \\
\text { effect } \\
\mathrm{E}^{\prime}\left(\mathrm{p}_{\mathrm{E}}-\mathrm{p}_{\mathrm{I}}\right)\end{array}$ & $\begin{array}{c}\text { Price-level } \\
\text { effect } \\
\left(\mathrm{p}_{\mathrm{I}}-1\right)\left(\mathrm{E}^{\prime}-\mathrm{I}^{\prime}\right)\end{array}$ \\
\hline 1949 & 0 & 0 & 0 \\
1950 & -582 & -567 & -15 \\
1951 & -1188 & -1566 & 378 \\
1952 & -740 & -1091 & 351 \\
1953 & -650 & -850 & 200 \\
1954 & -527 & -666 & 39 \\
1955 & -500 & -678 & 178 \\
1956 & -463 & -585 & 122 \\
1957 & -704 & -1037 & 333 \\
1958 & -473 & -776 & 303 \\
1959 & -49 & -88 & 39 \\
1960 & -473 & -486 & 13 \\
1961 & -724 & -741 & 17 \\
1962 & -611 & -428 & -183 \\
1963 & -231 & -354 & 123 \\
1964 & -208 & 12 & -220 \\
\hline
\end{tabular}

Also the terms-of-trade effect is, of course, particularly marked for the same years 1951-53 as well as 1957 and 1958. As will be seen, the gain from the terms-oftrade effect was -1566 mill. $\mathrm{kr}$. in 1951, - $1091 \mathrm{mill}$. $\mathrm{kr}$. in 1952, and - 1037 mill. kr. in 1957. 
This, in fact, corresponds to the changes which have taken place in the index for the terms of trade in foreign trade. Based on 1949-100, the indices for the mentioned years were as follows:

$\begin{array}{cc}1951 & 83 \\ 1952 & 87 \\ 1953 & 90 \\ . & \\ \cdot & \\ 1957 & 91 \\ 1958 & 94\end{array}$

For all the years, the index for the terms of trade in foreign trade will be seen in Table 3.

TABLE 3

INDEX FOR TERMS OF TRADE

\begin{tabular}{rrrr}
\hline & $\frac{p_{\mathrm{E}}}{\mathrm{p}_{\mathrm{I}}}$ & & $\frac{\mathrm{p}_{\mathrm{E}}}{\mathrm{p}_{\mathrm{I}}}$ \\
\hline 1949 & 100.0 & 1957 & 91.7 \\
1950 & 91.4 & 1958 & 93.9 \\
1951 & 83.3 & 1959 & 99.3 \\
1952 & 88.0 & 1960 & 96.6 \\
1953 & 90.6 & 1961 & 95.0 \\
1954 & 93.0 & 1962 & 97.3 \\
1955 & 93.5 & 1963 & 98.0 \\
1956 & 94.7 & 1964 & 100.1 \\
\hline
\end{tabular}

While, as mentioned, the index of the terms of trade for foreign trade fell sharply during the first few years, it improved somewhat during the following years, but was between 91 and 95 during the period 1953-1958. By 1959 it had reached 99, but it was somewhat lower in the following year, and in 1964 it touched 100. This development was also reflected in the gain from the terms-of-trade effect, which was only -88 mill. $\mathrm{kr}$. in 1959, and positive in 1964, viz. $12 \mathrm{mill}$. kr.

The above discussion shows that the development in the price relations with the rest of the world was adverse to Denmark throughout the period.

To get an impression of the order of magnitude of the mentioned total negative gain a comparison with the net national product has been made in Table 4 . The greatest share accounted for by the gain is $51 / 2$ per cent of the net national product, viz. in 1951, and the smallest 0.14 per cent in 1959.

\section{Intersectoral gain}

It was mentioned in the theoretical section that the following identity can be fulfilled:

$$
\mathrm{G}=\mathrm{G}_{1}+\mathrm{G}_{2}+\mathrm{G}_{3} \text { etc., }
$$

where $G$ is the gain from the terms of trade in foreign trade, and $G_{1}, G_{2}, G_{3}$ represent intersectoral gain. 
TABLE 4

Gain from Foreign Trade and the Net National Product

\begin{tabular}{cccc}
\hline & Gain & $\begin{array}{c}\text { Net national } \\
\text { product }\end{array}$ & \\
\cline { 2 - 3 } & $\begin{array}{c}\text { Millions of } \\
\text { kroner }\end{array}$ & $\begin{array}{c}\text { Millions of } \\
\text { kroner }\end{array}$ & $\begin{array}{c}\text { Gain as \% of } \\
\text { net national } \\
\text { product }\end{array}$ \\
\hline 1949 & 0 & 17,688 & 0 \\
1950 & -582 & 20,384 & -2.86 \\
1951 & -1188 & 21,639 & -5.49 \\
1952 & -740 & 22,970 & -3.22 \\
1953 & -650 & 24,639 & -2.64 \\
1954 & -627 & 25,783 & -2.43 \\
1955 & -500 & 26,796 & -1.87 \\
1956 & -463 & 28,587 & -1.62 \\
1957 & -704 & 30,323 & -2.32 \\
1958 & -473 & 31,649 & -1.49 \\
1959 & -49 & 35,206 & -0.14 \\
1960 & -473 & 37,953 & -1.25 \\
1961 & -724 & 42,062 & -1.72 \\
1962 & -611 & 47,425 & -1.29 \\
1963 & -231 & 50,298 & -0.46 \\
1964 & -208 & 56,608 & -0.37 \\
\hline
\end{tabular}

The main results of the calculations are shown in Table 5. It must be borne in mind that in these calculations the term $(E-I)$ has been divided by $p_{D}$ in the determination of the gain from foreign trade. Therefore, there will not be agreement with the figures in the first column of Table 1.

For industries the following formula has been used:

$$
\frac{1}{p_{D}} \cdot X_{v a}^{\prime}\left(p_{v a}-p_{D}\right)
$$

For the total (foreign trade) this formula has been used:

$$
\frac{E-I}{D}-\left(E^{\prime}-I^{\prime}\right)
$$

As the industries have been given in factor cost prices, it has been necessary to introduce an adjustment item for indirect taxes. Indirect taxes have been dealt with as an industry.

The table shows clearly that in agriculture and manufacturing industries, which are heavily dependent on foreign trade, the gains are negative as in the case of foreign trade. For building and construction the development is a different one, this typical home market industry not being affected to anything like the same extent by changes in the terms of trade for foreign trade. The domestic factors, such as the development in wages, result in the figures being positive for the greater part of the period. Danish shipping in foreign trade shows extremely varying movements, 
TABLE 5

Distribution of Gain from Terms of Trade by Industry. $1949=100$ (Millions of kroner)

\begin{tabular}{|c|c|c|c|c|c|c|c|}
\hline & $\begin{array}{l}\text { Agricul- } \\
\text { ture } \\
1\end{array}$ & $\begin{array}{c}\text { Manufac- } \\
\text { turing } \\
2\end{array}$ & $\begin{array}{c}\text { Building } \\
\text { and con- } \\
\text { struction } \\
3\end{array}$ & $\begin{array}{c}\text { Shipping } \\
\text { in foreign } \\
\text { trade } \\
4\end{array}$ & $\begin{array}{c}\text { Other } \\
\text { industries } \\
5\end{array}$ & $\begin{array}{c}\text { Indirect } \\
\text { taxes } \\
6\end{array}$ & $\begin{array}{c}\text { Total } \\
\text { (foreign } \\
\text { trade) } \\
7\end{array}$ \\
\hline 1950 & -172 & -115 & -19 & -10 & -92 & -117 & -525 \\
\hline 1951 & -348 & -352 & -20 & 152 & -529 & -56 & -1153 \\
\hline 1952 & -210 & -302 & 78 & 111 & -394 & -68 & -785 \\
\hline 1953 & -451 & -129 & 54 & 0 & -256 & 96 & -686 \\
\hline 1954 & -498 & -206 & 89 & 56 & -144 & 169 & -534 \\
\hline 1955 & -584 & -338 & 54 & 39 & -117 & 375 & -571 \\
\hline 1956 & -586 & -393 & 49 & 147 & -70 & 398 & -455 \\
\hline 1957 & -1184 & -323 & 91 & 222 & -24 & 406 & -812 \\
\hline 1958 & -1205 & -330 & 72 & 33 & 208 & 466 & -756 \\
\hline 1959 & -869 & -339 & 108 & 45 & 373 & 578 & -104 \\
\hline 1960 & -1198 & -357 & 131 & 7 & 471 & 607 & -339 \\
\hline 1961 & -1423 & -431 & 243 & -49 & 819 & 351 & -490 \\
\hline 1962 & -1530 & -472 & 274 & -68 & 1108 & 691 & 3 \\
\hline 1963 & -1284 & -810 & 206 & -76 & 683 & 908 & -373 \\
\hline 1964 & -1224 & -935 & 327 & -68 & 1131 & 1083 & 314 \\
\hline
\end{tabular}

which are due to the changes in the shipping market. For other industries it is difficult to say anything since this is a miscellaneous group which has been included as a balancing item.

To throw more light on the price factors which explain this difference in the development, the price development for value added and for final demand has been shown in Table 6.

The price development for value added for agriculture and manufacturing industries thus do not follow the price development for final demand, while the opposite is true of building and construction, which is a home market industry and a key industry.

There is nothing surprising in what has been mentioned above. The figures merely show what was to be expected, viz. how the adverse development in the terms of trade throughout the period has affected the export industries at the same time as industries such as building and construction have been favoured by the development.

Another interesting thing is the question how indices for terms of trade from a production point of view (I) and an income point of view (II) have developed for the individual industries. On the basis of the material available in the national accounts estimates, it is possible to illustrate-with a good degree of accuracy-the development for agriculture and-with a satisfactory degree of accuracy-for the three other industries shown in Table 7.

The figures show that although sectoral terms of trade $I$ in agriculture have not changed very much, index II shows a considerable fall, which is an expression of the fact that those consumer goods which agriculture must have from the urban industries have become relatively dearer. 
TABLE 6

Price Index for Value Added and for Final Demand

\begin{tabular}{|c|c|c|c|c|c|c|c|c|c|c|c|c|}
\hline & \multicolumn{2}{|c|}{ Agriculture } & \multicolumn{2}{|c|}{$\begin{array}{c}2 \\
\text { Manufacturing }\end{array}$} & \multicolumn{2}{|c|}{$\begin{array}{c}3 \\
\text { Building and } \\
\text { construction }\end{array}$} & \multicolumn{2}{|c|}{$\begin{array}{c}4 \\
\text { Shipping in } \\
\text { foreign trade }\end{array}$} & \multicolumn{2}{|c|}{$\begin{array}{c}5 \\
\text { Other } \\
\text { industries }\end{array}$} & \multicolumn{2}{|c|}{$\begin{array}{c}6 \\
\text { All } \\
\text { industries }\end{array}$} \\
\hline & $\mathrm{p}_{\mathrm{va}}$ & $\mathrm{p}_{\mathrm{D}}$ & $\mathrm{p}_{\mathrm{ya}}$ & $\mathrm{p}_{\mathrm{D}}$ & $\mathrm{p}_{\mathrm{va}}$ & $\mathrm{p}_{\mathrm{D}}$ & $\mathrm{p}_{\mathrm{va}}$ & $\mathrm{p}_{\mathrm{D}}$ & $\mathrm{p}_{\mathrm{va}}$ & $\mathrm{p}_{\mathrm{D}}$ & $\mathrm{p}_{\mathrm{va}}$ & $\mathrm{p}_{\mathrm{D}}$ \\
\hline 1949 & 100.0 & 100.0 & 100.0 & 100.0 & 100.0 & 100.0 & 100.0 & 100.0 & 100.0 & 100.0 & 100 & 100 \\
\hline 1950 & 103.6 & 108.4 & 105.2 & 108.4 & 106.8 & 108.4 & 105.7 & 108.4 & 107.4 & 108.4 & 107 & 108 \\
\hline 1951 & 110.1 & 121.1 & 110.3 & 121.1 & 119.3 & 121.1 & 161.7 & 121.1 & 115.2 & 121.1 & 114 & 121 \\
\hline 1953 & 112.8 & 125.6 & 121.4 & 125.6 & 130.0 & 125.6 & 125.5 & 125.6 & 122.8 & 125.6 & 120 & 126 \\
\hline 1954 & 112.1 & 127.5 & 121.2 & 127.5 & 134.7 & 127.5 & 143.7 & 127.5 & 126.0 & 127.5 & 122 & 127 \\
\hline 1955 & 113.9 & 132.7 & 122.3 & 132.7 & 137.6 & 132.7 & 142.4 & 132.7 & 131.5 & 132.7 & 126 & 133 \\
\hline 1956 & 119.3 & 138.3 & 125.8 & 138.3 & 142.8 & 138.3 & 173.5 & 138.3 & 137.5 & 138.3 & 132 & 138 \\
\hline 1957 & 105.5 & 141.7 & 131.8 & 141.7 & 150.0 & 141.7 & 190.9 & 141.7 & 141.4 & 141.7 & 133 & 142 \\
\hline 1958 & 105.4 & 144.1 & 134.2 & 144.1 & 150.6 & 144.1 & 151.6 & 144.1 & 146.4 & 144.1 & 136 & 144 \\
\hline 1959 & 116.5 & 146.3 & 137.1 & 146.3 & 155.2 & 146.3 & 156.3 & 146.3 & 150.1 & 146.3 & 142 & 146 \\
\hline 1960 & 110.7 & 149.8 & 140.8 & 149.8 & 160.1 & 149.8 & 151.2 & 149.8 & 154.5 & 149.8 & 143 & 150 \\
\hline 1963 & 126.6 & 178.3 & 157.3 & 178.3 & 195.1 & 178.3 & 159.5 & 178.3 & 185.4 & 178.3 & 169 & 178 \\
\hline 1964 & 135.7 & 183.5 & 161.2 & 183.5 & 206.8 & 183.5 & 167.3 & 183.5 & 195.1 & 183.5 & 177 & 184 \\
\hline
\end{tabular}


TABLE 7

INDEX FOR INTERSECTORAL Terms of TRADE

\begin{tabular}{|c|c|c|c|c|c|c|c|c|}
\hline & \multicolumn{2}{|c|}{ Agriculture } & \multicolumn{2}{|c|}{ Manufacturing } & \multicolumn{2}{|c|}{$\begin{array}{c}\quad 3 \\
\text { Building and } \\
\text { construction }\end{array}$} & \multicolumn{2}{|c|}{$\begin{array}{c}4 \\
\text { Shipping in } \\
\text { foreign trade }\end{array}$} \\
\hline & $\mathrm{p}_{0}$ & $\mathrm{p}_{0}$ & $\mathrm{p}_{0}$ & $\mathrm{p}_{0}$ & $\mathrm{p}_{0}$ & $\mathrm{p}_{0}$ & $\mathrm{p}_{0}$ & $\mathrm{p}_{0}$ \\
\hline & $\mathrm{p}_{\text {in }}$ & $p_{\text {in }} \cdot V_{\text {in }}+p_{D} \cdot V_{D}$ & $\mathrm{p}_{\mathrm{in}}$ & $\mathrm{p}_{\mathrm{in}} \cdot \mathrm{V}_{\mathrm{in}}+\mathrm{p}_{\mathrm{D}} \cdot \mathrm{V}_{\mathrm{D}}$ & $p_{\text {in }}$ & $p_{\text {in }} \cdot V_{\text {in }}+p_{D} \cdot V_{D}$ & $\mathrm{p}_{\text {in }}$ & $p_{i n} \cdot V_{i n}+p_{D} \cdot V_{D}$ \\
\hline 1949 & 100.0 & 100.0 & 100.0 & 100.0 & 100.0 & 100.0 & 100.0 & 100.0 \\
\hline 1950 & 94.0 & 96.6 & 97.0 & 98.8 & 100.8 & 99.2 & 95.5 & 98.8 \\
\hline 1951 & 95.6 & 92.9 & 90.3 & 96.5 & 92.9 & 99.2 & 107.4 & 116.6 \\
\hline 1952 & 96.7 & 95.9 & 91.6 & 96.8 & 97.7 & 103.0 & 106.5 & 112.1 \\
\hline 1953 & 97.1 & 92.0 & 96.0 & 98.6 & 100.6 & 101.9 & 100.7 & 100.0 \\
\hline 1954 & 97.8 & 90.5 & 96.3 & 98.0 & 103.5 & 103.1 & 101.5 & 98.7 \\
\hline 1955 & 95.4 & 89.0 & 95.3 & 96.7 & 102.5 & 102.0 & 104.7 & 103.9 \\
\hline 1956 & 98.0 & 89.2 & 94.3 & 96.2 & 102.0 & 101.8 & 114.1 & 113.7 \\
\hline 1957 & 90.5 & 79.6 & 95.7 & 97.1 & 103.6 & 103.2 & 113.4 & 118.0 \\
\hline 1958 & 96.7 & 78.2 & 96.5 & 97.1 & 104.9 & 102.5 & 107.8 & 102.9 \\
\hline 1959 & 99.9 & 83.5 & 97.3 & 97.3 & 107.4 & 103.5 & 108.1 & 103.8 \\
\hline 1960 & 97.9 & 78.9 & 98.3 & 97.4 & 106.4 & 103.9 & 106.7 & 100.6 \\
\hline 1961 & 99.3 & 75.3 & 100.2 & 97.2 & 109.0 & 106.5 & 104.7 & 96.0 \\
\hline 1962 & 97.0 & 73.8 & 101.8 & 96.9 & 109.6 & 106.9 & 105.3 & 94.4 \\
\hline 1963 & 101.4 & 75.7 & 101.4 & 94.6 & 108.6 & 105.3 & 107.7 & 93.7 \\
\hline 1964 & 105.9 & 77.4 & 100.3 & 94.4 & 109.9 & 107.1 & 109.2 & 94.7 \\
\hline
\end{tabular}


A similar consideration is true of manufacturing industries, if in a more temperate form. On the other hand, there seems to be no significant difference in the development for a home market industry as typical as building and construction. For domestic shipping there are rather wide fluctuations, which are due to the rather rapidly changing shipping market dependent on freight rates.

The purpose of this article has been to discuss the fact that there seems to be no unique solution to the terms of trade problem, and also to illustrate through some calculations for Denmark the influence which changes in the terms of trade for foreign trade might have for the country as a whole and for the individual industries.

\section{BIBLIOGRAPHY}

[1] Richard Stone: Quantity and Price Indexes in National Accounts, O.E.E.C., 1956.

[2] Ragnar Frisch: "Annual Survey of General Economic Theory; The Problem of Index Numbers", Econometrica, 1936.

[3] Kjeld Bjerke, Leo Meyer and P. Nørregaard Rasmussen: "Ueber die Deflationierung der volkswertschaftlichen Gesamtrechnung", Weltwirtschaftliches Archiv, 1963.

[4] J. L. Nicholson: "The Effects of International Trade on the Measurements of Real National Income", paper prepared for the Sixth Conference of the International Association for Research in Income and Wealth, 1959.

[5] R. C. Geary and R. W. Burge, "Balancing of a System of National Accounts in Real Terms", paper presented to the Fifth Conference of the IARIW, De Pietersberg, 1957. "Productivity Aspects of Accounts Deflation", Income and Wealth, Series IX, London 1961. See also R. W. Burge, "Deflation within an Accounting Framework", Income and Wealth, Series IX, London 1961, and "A System of Price and Quantity Indexes for National Accounts", United Nations, E/CN. 3/L46, 27. Dec. 1957.

[6] G. Stuvel: "The Use of National Accounts in Economic Analysis", Income and Wealth, Series IV, London 1955.

[7] G. Stuvel: "Asset Re-evaluation and Terms-of-Trade Effects in the Framework of the National Accounts", The Economic Journal, June 1959.

[8] P. Nørregaard Rasmussen: Studies in Inter-Sectoral Relations, 1956.

[9] Anders Ølgaard: Growth, Productivity and Relative Prices, 1966.

Dans mon article, j'ai envisagé les différentes définitions des termes de l'échange. J'ai trouvé particulièrement intéressant de diviser le gain total en deux parties; plus précisement, Ia partie due aux effets sur les termes de l'échange et celle due aux effets sur le niveau des prix. J'ai aussi soulevé le problème du gain intersectorial des termes de l'échange et de ses rapports avec les termes de l'échange dans le commerce international. A côté de l'habituel indice des termes de l'échange - rapport entre les prix des extrants et ceux des intrants j'ai voulu introduire un autre indice pour les termes de l'échange qui correspond au rapport entre l'indice des prix des entrants et un indice consistent en une moyenne pondérée des prix des intrants et des prix de la demande finale. Finalement, j'ai essayé de donner quelques résultats empiriques qui devraient jeter la lumière sur le développement des terms de l'échange danois durant la période 1949-1964. 